\title{
Association and Path Analysis of Yield and its Components in Aerobic Rice (Oryza sativa L.)
}

\author{
P. Madhukar ${ }^{1 *}$, CH. Surender Raju ${ }^{3}$, P. Senguttuvel ${ }^{4}$ and S. Narender Reddy ${ }^{2}$ \\ ${ }^{1}$ Department of Genetics and Plant Breeding, ${ }^{2}$ Department of Crop Physiology, \\ College of Agriculture, PJTSAU, Hyderabad-30, India \\ ${ }^{3}$ Rice Research Station, Agriculture Research Institute, \\ PJTSAU, Rajendranagar, Hyderabad-30, India \\ ${ }^{4}$ Crop Improvement Section, ICAR-Indian Institute of Rice Research, \\ Rajendranagar, Hyderabad-30, India \\ *Corresponding author
}

A B S T R A C T

\begin{tabular}{|l|}
\hline Ke y w o r d s \\
Correlation, \\
$\begin{array}{l}\text { Path analysis } \\
\text { and aerobic rice. }\end{array}$ \\
\hline Article Info \\
\hline $\begin{array}{l}\text { Accepted: } \\
\text { 17 July } 2017 \\
\text { Available Online: } \\
\text { 10 September } 2017\end{array}$ \\
\hline
\end{tabular}

A critical analysis of both character association and path analysis indicated that among several yield components in rice, number of filled grains per panicle are playing key role for better yields under aerobic situation. The studies indicated that grain yield is primarily contributed by filled grains per panicle and 1000 seed weight. As a highly significant correlation was noticed between panicle length and plant height and also between panicle length and grains per panicle, stature of plant is very important under aerobic condition. Hence medium stature plant with long panicle, sturdy culms and more grains per panicle would be highly advantageous for this situation. Other important traits for simultaneous consideration for yield enhancement are spikelet fertility and 1000 seed weight.

\section{Introduction}

In Telangana state rice is the principal food crop grown in $16.0 \mathrm{~L}$. ha under irrigated ecosystem with an average productivity of $3.24 \mathrm{t} / \mathrm{ha}$ (Milled rice). More than $50 \%$ of the water resources from wells, tanks and project canals are diverted for this crop at the cost of other crops and requirements. In addition to this, labour scarcity is becoming a major threat to rice cultivation and in coming 5-10 years total rice cultivation has to be mechanized. At this juncture, innovative technologies are required to use the water most economically without yield sacrifice. This system of rice cultivation would be more successful in the state, provided location specific high yield potential hybrids with acceptable cooking quality are developed and it is need of the day too. The association of different component characters among themselves and with yield is quite important for planning an efficient selection criterion for yield under aerobic cultivation. The total 
correlation between yield and component characters may be some times misleading, as it might be an over estimate or under estimate because of its association with other characters. Hence, indirect selection by correlated response may not be some times fruitful. When many characters are affecting a given character, splitting the total correlation into direct and indirect effects of cause as devised by wright (1921) would give more meaningful interpretation to the cause of association between the dependent variable like yield and independent variables like yield components.

This kind of information in aerobic situation is studied in rice. On account of this, statistical analysis was carried out to estimate the correlation, direct and indirect effect to facilitate selection of better hybrids. This study was conducted to determine the nature of relationship between grain yield and yield components, direct and indirect contribution of these parameters towards paddy yield and to identify better combination as selection criteria for developing high yielding rice genotypes under aerobic condition.

\section{Materials and Methods}

A total of 32 hybrids along with eight restorers, four ' $\mathrm{B}$ ' lines of corresponding male sterile lines and 3 checks (MTU-1010, CR dhan-201 and MAS-946) were sown under aerobic situation at Rice Research Centre, Rajendranagar, Hyderabad.

Crossed seeds of hybrids were treated with Carbendazim solution $(0.1 \%)$ and got them germinated in petridishes. Sprouted seeds were sown under aerobic situation and irrigated immediately.

A completely randomized block design with three replications was followed. Top dressing was given with urea and need based plant protection measures were undertaken for raising healthy seedlings. Five plants were selected at random from each entry in each replication. Observations were recorded (on 32 hybrids, 12 parents and 3 checks) for yield and yield attributing traits viz., days to $50 \%$ flowering, plant height, panicle length, number of effective tillers per plant, total number of filled grains per panicle, spikelet fertility \%, 1000 seed weight. Observations were recorded and the data was subjected to statistical analysis. Statistical analyses for the above characters were done following Singh and Chaudhary (1995) for correlation coefficient and Dewey and Lu (1959) for path analysis.

\section{Results and Discussion}

Correlation coefficients were estimated involving 47 genotypes (32 hybrids, 12 parents and 3 checks) were presented in table 1. The grain yield per plant had significant positive association with plant height, panicle length, spikelet fertility and 1000 seed weight.

Similar kinds of results were reported by Adithya et al., (2013), Khare et al., (2014), Jambhulkar et al., (2014) and Pavan Shankar et al., (2016) for the traits plant height, 1000 seed weight. Hence, desired height with sturdiness could be considered as criteria for raising yield ceiling in aerobic condition.

The character days to $50 \%$ flowering expressed significant positive association with plant height while it showed negative significant association with spikelet fertility as was reported by Chandan kumar et al., (2014) and Venkanna et al., (2014).

Panicle length showed significant positive correlation with number of grains per panicle, filled grains per panicle and grain yield per plant. Earlier researchers, Rajamadhan et al., (2011), Adithya et al., (2013), Singh et al., 
(2013), Patel et al., (2014), Khare et al., (2014), Fantie et al., (2014) and Pavan shankar et al., (2016) reported similar results. The trait number of filled grains per panicle is considered as an important component for realizing high yield, because it exhibited significant and positive association with plant height, panicle length and total number of grains per panicle while it registered negative relationship with 1000 grain weight (Nandan et al., 2010).

The trait, spikelet fertility (\%) was found to possess positive and significant association with grain yield per plant (Haider et al., 2012, Singh et al., 2013 and Chandan kumar et al., 2014). It expressed negative relationship with days to $50 \%$ flowering and total number of grains per panicle.

The studies finally indicated that grain yield is primarily contributed by filled grains per panicle and 1000 seed weight. As a highly significant correlation was noticed between panicle length and plant height and also between panicle length and grains per panicle, stature of plant is very important under aerobic condition. Hence medium tall (120$130 \mathrm{~cm}$ ) with sturdy, non-lodging stems having long panicles and more grains per panicle would be highly advantageous. Semi tall statured plants also mostly have extensive root system; they are preferable under water scarce situation.

Data recorded on 47 genotypes (32 hybrids and 12 parents with three check) were subjected to analysis for estimation of correlation coefficients first, than they were further split into direct and indirect effects to know the cause and effect of each trait on yield

(Table 2).

Days to $50 \%$ flowering had minimum direct effect on grain yield (0.0442). Positive but low level of indirect effects were exhibited on grain yield per plant by this trait via plant height, number of productive tillers per plant and number of filled grains per panicle.

Yadav et al., (2010), Seyoum et al., (2012), Pandey et al., (2012), Yadav and Rajendra kumar (2012), Haider et al., (2012) and khare et al., (2014) also reported that plant height had positive direct effect on grain yield, but small extent (0.0127) as in the case of present study. The indirect effects of this trait on grain yield per plant were expressed via days to $50 \%$ flowering, panicle length, number of productive tillers per plant and number of filled grains per panicle, spikelet fertility and 1000 seed weight, among these, the effect was high through number of filled grains per panicle.

Number of productive tillers per plant also exhibited positive direct effect (0.256) on grain yield per plant but low, when compare to grains per panicle. Results reported by Patel et al., (2014) and Thirumala Rao et al., (2014) are almost in agreement with the presently observed findings. It is interesting to note that productive tillers had positive indirect effects through all the other yield components except total number of grains per panicle.

Highest level of positive direct effect was exhibited by number of filled grains per panicle on grain yield per plant (0.4021), indicating its greater role in higher yield.

Earlier Pandey et al., (2012), Seyoum et al., (2012), Adithya et al., (2013), Khare et al., (2014), Patel et al., (2014) and Thirumala Rao et al., (2014) also reported that number of filled grains per panicle were very important among yield components. This trait also displayed desirable effects through all the traits studied except total number of grains per panicles and 1000 grain weight. 
Table.1 Simple correlation coefficients for grain yield and yield components

\begin{tabular}{|c|c|c|c|c|c|c|c|c|c|}
\hline Characters & $\begin{array}{c}\text { Days to } \\
50 \% \\
\text { flowering } \\
\end{array}$ & $\begin{array}{c}\text { Plant } \\
\text { height }\end{array}$ & $\begin{array}{l}\text { Panicle } \\
\text { length }\end{array}$ & $\begin{array}{c}\text { Productive } \\
\text { tillers / } \\
\text { plant } \\
\end{array}$ & $\begin{array}{c}\text { Total No. of } \\
\text { grains/panicle }\end{array}$ & $\begin{array}{c}\text { No. of Filled } \\
\text { grains/panicle }\end{array}$ & $\begin{array}{l}\text { Spikelet } \\
\text { fertility }\end{array}$ & $\begin{array}{l}1000 \text { seed } \\
\text { weight }\end{array}$ & $\begin{array}{c}\text { Seed yield } \\
\text { / plant }\end{array}$ \\
\hline $\begin{array}{l}\text { Days to } 50 \% \\
\text { flowering }\end{array}$ & 1.0000 & $0.2983 *$ & 0.0915 & 0.1900 & 0.276 & 0.1968 & $-0.3016 *$ & -0.0455 & 0.1158 \\
\hline Plant height & & 1.0000 & $0.7361 * *$ & 0.0966 & $0.3289 *$ & $0.3581 *$ & 0.0501 & $0.3157 *$ & $0.5016 * *$ \\
\hline Panicle length & & & 1.0000 & -0.0290 & $0.3128 *$ & $0.2903 *$ & 0.1451 & $0.3003 *$ & $0.4107 * *$ \\
\hline $\begin{array}{l}\text { Productive tillers } \\
\text { / plant }\end{array}$ & & & & 1.0000 & 0.1624 & 0.1294 & -0.1179 & -0.0151 & $0.2906 *$ \\
\hline $\begin{array}{l}\text { Total No. } \\
\text { grains/panicle }\end{array}$ & & & & & 1.0000 & $0.9281 * *$ & $-0.3708 *$ & $-0.3215 *$ & 0.0766 \\
\hline $\begin{array}{l}\text { No. of Filled } \\
\text { grains/panicle }\end{array}$ & & & & & & 1.0000 & -0.0134 & -0.2733 & $0.3239 *$ \\
\hline Spikelet fertility & & & & & & & 1.0000 & 0.224 & $0.3598 *$ \\
\hline 1000 seed weight & & & & & & & & 1.0000 & $0.3891 * *$ \\
\hline Seed yield / plant & & & & & & & & & 1.0000 \\
\hline
\end{tabular}

*Significant at $5 \%$ level; **Significant at $1 \%$ level

Table.2 Path coefficient analysis for yield and yield contributing characters

\begin{tabular}{|c|c|c|c|c|c|c|c|c|c|}
\hline Characters & $\begin{array}{c}\text { Days to } \\
50 \% \\
\text { flowering } \\
\end{array}$ & $\begin{array}{c}\text { Plant } \\
\text { height }\end{array}$ & $\begin{array}{l}\text { Panicle } \\
\text { length }\end{array}$ & $\begin{array}{l}\text { Productive } \\
\text { tillers / plant }\end{array}$ & $\begin{array}{l}\text { Total No. of } \\
\text { grains/panicle }\end{array}$ & $\begin{array}{l}\text { No. of Filled } \\
\text { grains/panicle }\end{array}$ & $\begin{array}{l}\text { Spikelet } \\
\text { fertility }\end{array}$ & $\begin{array}{c}1000 \\
\text { seed } \\
\text { weight }\end{array}$ & $\begin{array}{c}\text { Seed yield } / \\
\text { plant }\end{array}$ \\
\hline Days to $50 \%$ flowering & 0.0442 & 0.0567 & 0.0068 & 0.0473 & -0.0751 & 0.0749 & -0.0333 & -0.0095 & 0.1121 \\
\hline Plant height & 0.0127 & 0.1967 & 0.06 & 0.0543 & -0.0882 & 0.1333 & 0.0053 & 0.0711 & 0.4453 \\
\hline Panicle length & 0.0033 & 0.1303 & 0.0905 & 0.016 & -0.0537 & 0.0978 & 0.0136 & 0.0656 & 0.3635 \\
\hline Productive tillers / plant & 0.0082 & 0.0417 & 0.0057 & 0.256 & -0.0398 & 0.0576 & 0.0035 & 0.0066 & 0.3395 \\
\hline Total No. of grains/panicle & 0.011 & 0.0574 & 0.0161 & 0.0337 & -0.302 & 0.3726 & -0.0452 & -0.0703 & 0.0732 \\
\hline No. of Filled grains/panicle & 0.0082 & 0.0652 & 0.022 & 0.0367 & -0.2798 & 0.4021 & 0.0016 & -0.058 & 0.198 \\
\hline Spikelet fertility & -0.0115 & 0.0083 & 0.0096 & 0.007 & 0.1071 & 0.005 & 0.1275 & 0.0481 & 0.301 \\
\hline 1000 seed weight & -0.0017 & 0.0564 & 0.0239 & 0.0068 & 0.0856 & -0.0941 & 0.0247 & 0.2481 & 0.3498 \\
\hline
\end{tabular}

Bold values are direct effects, residual effect $=0.7778$ 
Another important yield contributing trait is spikelet fertility (\%), as evident from positive direct effect of 0.1275 on grain yield. Indirect positive influence of spikelet fertility on grain yield was observed through plant height, total number of grains per panicle and 1000 seed weight while it showed negative influence through days to $50 \%$ flowering.

Next important trait, which showed moderate positive direct effect $(0.2481)$ on grain yield per plant was 1000 grain weight. With respect to indirect effects, positive effects on yield were through plant height, productive tillers per plant, total number of grains per panicle and spikelet fertility, whereas negative effects were observed through days to $50 \%$ flowering and number of filled grains per panicle.

Path coefficient analysis revealed that among the yield components, the quantitative trait, number of filled grains per had highest positive direct effect on grain yield followed by number of productive tillers per plant, 1000 seed weight, plant height, spikelet fertility and days to $50 \%$ flowering. Earlier findings of Pandey et al., (2012), for number of productive tillers per plant and panicle length; Seyoum et al., (2012), Yadav and Rajendrakumar (2012) for number of filled grains per panicle) were also in same lines.

A critical analysis of both character association and path analysis indicated that among the yield components in rice, number of filled grains per panicle and number of productive tillers per plant were determined. Other important traits for simultaneous consideration for yield enhancement are spikelet fertility, plant height and 1000 seed weight under aerobic situation.

\section{References}

Adithya, J.P., and Anuradha, B. 2013. Genetic variability, correlation and path analysis for quantitative characters in rainfed upland rice of uttarakhand hills. Journal of Rice Research. 6 (2): 24-34.

Chandan Kumar, and Nilanjaya. 2014. Correlation and path coefficient analysis of yield components in aerobic rice (Oryza sativa L.). The Bioscan. 9 (2): 907-913.

Dewey, J.R., and Lu, K. H. 1959. Correlation and path coefficient analysis of components of crested wheat grass seed production. Agronomy Journal. 51: 515518.

Fantie, D., Getachew, A., Mahesh, S and Tilahun, T. 2014. Genetic variability, heritability and correlation coefficient analysis for yield and yield component traits in upland rice (Oryza sativa L.). East African Journal of Sciences. 8 (2): $147-154$.

Haider, Z., Abdus S. K and Samta, Z. 2012. Correlation and path coefficient analysis of yield components in rice (Oryza sativa L.) under simulated drought stress condition. American Eurasian Journal of Agriculture and Environment Science. 12 (1): 100-104.

Jambhulkar, N.N., and Lotan Kumar, B. 2014. Genetic variability and association of yield attributing traits with grain yield in upland rice. Genetika. 46 (3): 831838.

Khare, R., Singh, A. K., Eram, S. and Singh, P. K. 2014. Genetic variability, association and diversity analysis in upland rice (Oryza sativa L.). SAARC Journal of Agriculture. 12 (2): 40-51.

Nandan, R., Sweta and Singh, S.K. 2010. Character association and path analysis in rice (Oryza sativa L.) genotypes. World Journal of Agricultural Sciences. 6 (2): 201-206.

Patel, J.R., Saiyad, M. R., Prajapati, K. N., Patel, R. A and Bhavani, R. T. 2014. Genetic variability and character association studies in rainfed upland 
rice (Oryza sativa L.). Electronic Journal of Plant Breeding. 5 (3): 531537.

Pavan Shankar, H.P., Krishna Veni, B., Dayal Prasad Babu, J and Srinivasa Rao, V. 2016. Assessment of genetic variability and association studies in dry direct sown rice (Oryza sativa L.). Journal of Rice Research. 9 (2): 11-16.

Rajamadhan, R., Eswaran, R and Anandan, A. 2011.Investigation of correlation between traits and path analysis of rice (Oryza sativa L.) grain yield under coastal salinity. Electronic Journal of Plant Breeding. 2 (4): 538-542.

Seyoum, M., Alamerew, S and Bantte, K. 2012. Genetic variability, heritability, correlation coefficient and path analysis for yield and yield related traits in upland rice. Journal of Plant Sciences. 7 (1): 13-22.

Singh, R.K., and Chaudhary, B.D. 1985. Biometrical Methods in Quantitative Genetic Analysis. Kalyani Publishers, New Delhi.

Singh, Singh, A.K., Parveen Sharma and Singh, P.K. 2013. Studies on genetic characteristic of upland rice (Oryza sativa L.). International Journal of Agriculture, Environment and Biotechnology. 6 (4): 515-520.

Thirumala Rao, V., Chandra Mohan, Y., Bhadru, D., Bharathi, D and Venkanna, V. 2014. Genetic variability and association analysis in rice. International Journal of Applied Biology and Pharmaceutical Technology. 5(2):63-65.

Venkanna, V., Rao, M.V.B, Raju, CH.S, Rao, V.T and Lingaiah, N.2014. Association analysis of $\mathrm{F}_{2}$ generation in rice (Oryza sativa L.). International Journal of Pure Applied Bioscience. 2 (2): 278-283.

Wright, S. 1921. Correlation and causation. Journal of Agricultural Research. 20: 557- 585.

Yadav, S.K., Suresh, B.G., Praveen Pandey and Binod Kumar. 2010. Assessment of genetic variability, correlation and path association in rice (Oryza sativa L.). Journal of Biosciences. 18 (2): 1-8.

Yadav, V.K., and Rajendra Kumar. 2012. Characters association and path analysis of yield and its components in aromatic rice (Oryza sativa L.) genotypes. Plant Archives. 12 (2): 607-611.

\section{How to cite this article:}

Madhukar, P., CH. Surender Raju, P. Senguttuvel and Narender Reddy, S. 2017. Association and Path Analysis of Yield and its Components in Aerobic Rice (Oryza sativa L.). Int.J.Curr.Microbiol.App.Sci. 6(9): 1335-1340. doi: https://doi.org/10.20546/ijcmas.2017.609.161 